\title{
THE MERAH MOSQUE AND THE ASY SYAFI'I MOSQUE CONSIDERED AS LANDMARKS BASED ON THE LOCAL COMMUNITY'S RECOGNITION IN CIREBON'S ARAB PANJUNAN KAMPONG
}

\author{
${ }^{1}$ Ajeng Triwuri Widyastuti. ${ }^{2}$ Dr. Giosia Pele Widjaja, S.T., M.T. \\ ${ }^{I}$ Student in the Bachelor's (S-1) Study Program in Architecture \\ at Parahyangan Catholic University \\ ${ }^{2}$ Senior lecturer in the Bachelor's (S-1) Study Program in Architecture \\ at Parahyangan Catholic University
}

\begin{abstract}
The Arab Panjunan kampong serving as the research object happens to be one of the heritage areas of Cirebon Town. This urban kampong has certain ethnic characteristics typical of Arab quarters that make it unique, thus contributing to the rich cultural history of Cirebon. As a heritage area, it is important for this ethnic Arab neighbourhood of Panjunan to draw up an inventory of the specific architectural elements that are still traceable, such as the urban lay-out and its contents as well as the landmarks of this area observed from a physical-spatial angle. The aim of this research project is to find out about this kampong's various architectural elements that are recognized as such by the locals. This will be the contributing factor in the process of determining which environmental elements can be classified as typical landmarks. The first step taken in the research conducted is field observation in order to establish the elements that have survived in the kampong, including the architectural, social, and cultural ones. The observation related to architectural elements has been identified in accordance with the theory concerning Elements of Urban Design as proposed by Hamid Shirvani in his book The Urban Design Process. The next step is conducting research using the Cognitive Method as applied to the kampong dwellers in Panjunan by way of sketched maps and guided interviews. The respondents, classified based on ethnic heritage (descent) and gender, were requested to describe the environmental elements in this ethnic Arab kampong as far as they could recognize or identify them. Those who experienced difficulties in describing the sketches were assisted by the researcher based on the stories that had been supplied. Based on the acquired data containing these environmental elements, the aspect of memories contained therein was studied by way of interviews linked to the Continuity Theory by Breakwell. Subsequently, an analysis was made of the basis underlying the recognition of these elements based on the Landmark Theory by Kevin Lynch, and classified based on the criteria drawn up by Eko Budihardjo. Through the analysis, it was discovered that Panjunan's Merah Mosque and its Asy Syafi'i Mosque indeed qualify as as architectural elements that show continuity of memory, gaining validity as iconic elements or landmarks on the regional scale of Cirebon's ethnic Arab kampong of Panjunan.
\end{abstract}

\section{MASJID MERAH DAN MASJID ASY SYAFI'I SEBAGAI TENGARAN BERDASARKAN REKOGNISI KOMUNITAS LOKAL DI KAMPUNG ARAB PANJUNAN, CIREBON}

\author{
${ }^{1}$ Ajeng Triwuri Widyastuti. ${ }^{2}$ Dr. Giosia Pele Widjaja, S.T., M.T. \\ ${ }^{1}$ Mahasiswa S1 Program Studi Arsitektur Universitas Katolik Parahyangan. \\ ${ }^{2}$ Dosen Pembimbing S1 Program Studi Arsitektur Universitas Katolik Parahyangan.
}

Abstrak- Kampung Arab Panjunan sebagai objek penelitian merupakan salah satu Kawasan Pusaka Kota
Cirebon. Kampung kota ini memiliki karakteristik etnis Arab yang menjadikannya unik serta kaya akan sejarah

${ }^{1}$ Corresponding Author: widyastutiajeng@gmail.com 
Kota Cirebon. Sebagai Kawasan Pusaka, penting bagi Kampung Arab Panjunan untuk memiliki inventarisasi elemen arsitektural yang masih dapat ditelusuri seperti tata ruang kota beserta isinya serta tengaran kawasan tersebut dalam kacamata fisik-spasial. Penelitian ini bertujuan untuk mengetahui elemen-elemen arsitektural di Kampung Arab Panjunan yang direkognisi oleh warga setempat. Hal ini akan memberi kontribusi dalam proses mengetahui elemen-elemen lingkungan yang menjadi tengaran. Langkah pertama yang dilakukan dalam penelitian ini adalah observasi lapangan untuk mengetahui elemen yang masih bertahan pada Kampung Arab Panjunan, baik elemen arsitektural, sosial, maupun budaya. Observasi terkait elemen arsitektural diidentifikasi sesuai teori Elemen Perancangan Kota oleh Hamid Shirvani dalam buku The Urban Design Process. Langkah selanjutnya yaitu penelitian dengan metode kognitif warga Kampung Arab Panjunan melalui peta sketsa dan wawancara terarah. Responden yang diklasifikasikan berdasarkan keturunan dan jenis kelamin diminta menggambarkan elemen lingkungan pada Kampung Arab Panjunan yang mereka kenali. Responden yang kesulitan dalam menggambarkan sketsa dibantu oleh peneliti berdasarkan cerita yang disampaikan. Berdasarkan data elemen lingkungan yang didapat, ditelaah aspek memori di dalamnya melalui wawancara dan dihubungkan dengan teori Kontinuitas oleh Breakwell. Kemudian dianalisis tentang dasar rekognisi elemen tersebut berdasarkan teori Landmark oleh Kevin Lynch dan diklasifikasikan berdasarkan kriteria oleh Eko Budihardjo. Melalui analisa, ditemukan bahwa Masjid Merah Panjunan dan Masjid Asy Syafii adalah elemen arsitektural yang memiliki kontinuitas memori serta berlaku sebagai elemen tengaran skala kawasan pada Kampung Arab Panjunan Cirebon.

Kata-kata kunci : masjid, tengaran, rekognisi komunitas lokal, Kampung Arab Panjunan

\section{PENDAHULUAN}

\subsection{LATAR BELAKANG PENELITIAN}

Kota Pusaka adalah kota atau kabupaten di Indonesia yang memiliki aset pusaka unggul berupa warisan (pusaka) alam dan budaya yang lestari, termasuk di dalamnya artefak, bangunan, dan kawasan dengan ruang terbukanya. Salah satu kota pusaka di Indonesia adalah Kota Cirebon. Sebagai kota yang terletak di pesisir utara Pulau Jawa, Kota Cirebon menjadi simpul transportasi antara Jawa Barat dan Jawa Tengah atau yang biasa disebut jalur Pantura. Oleh karenanya, tak heran apabila dahulu kala kota ini merupakan kota strategis yang dilalui oleh pedagang dari Arab, Persia, Cina, India, dan sebagainya. Para pedagang ini kemudian menetap di Kota Cirebon, sehingga kota ini mengalami banyak akulturasi budaya. Permukiman para pendatang (pedagang) ini dikelompokkan berdasarkan kota atau negara asal mereka, serta berdasarkan pekerjaannya. Contohnya Kampung Arab Panjunan, yaitu sebutan untuk kampung para pendatang dari Arab yang berprofesi sebagai pengrajin gerabah (anjun).

Berdasarkan Rencana Aksi Kota Pusaka (RAKP) Kota Cirebon yang dikeluarkan oleh pemerintah setempat, Kampung Arab Panjunan termasuk dalam salah satu kawasan prioritas yang perlu dilestarikan. Kampung Arab Panjunan adalah perkampungan kuno yang terletak di pusat Kota Cirebon dan memiliki peran penting dalam perkembangan sejarah Indonesia, khususnya terkait perkembangan sejarah Islam di Pulau Jawa. Kawasan ini dikatakan sebagai perkampungan kuno karena dulunya merupakan kawasan permukiman warga keturunan Arab yang sudah tinggal secara turun temurun sejak Pangeran Panjunan dan para pengikutnya menempati daerah ini. Semenjak masa itu, kawasan ini lebih dikenal dengan sebutan Kampung Arab oleh warga sekitar.

Potensi historis yang terdapat pada kawasan prioritas sebagai bagian dari Kota Pusaka sejatinya merupakan elemen penting bagi pertumbuhan sebuah wilayah dan kota. Sebagai salah satu kawasan prioritas, Kampung Arab Panjunan perlu dilestarikan karena di dalamnya terdapat nilai-nilai penting, antara lain nilai jati diri atau identitas bangsa, kesejarahan, lingkungan, sosial, politik, ideologi, ekonomi dan budaya. Dalam kata lain, tiap-tiap unit 
kawasan prioritas dalam kota pusaka seyogyanya memiliki identitas kultural yang jelas sehingga kekayaan historis yang dimiliki tak luntur seiring berkembangnya zaman.

Modernisasi seolah menjadi suatu hal yang di salah satu sisi justru memudarkan kearifan budaya lokal, sehingga identitas lokal semakin terpinggirkan dan mendapatkan ancaman serius dalam upaya pelestariannya. Dari segi arsitektur, salah satu upaya yang dapat dilakukan untuk melestarikan Kampung Arab Panjunan adalah dengan inventarisasi elemen arsitektural apa yang masih dapat ditelusuri seperti tata ruang kota beserta isinya serta penciri kawasan itu sendiri dalam kaca mata fisik-spasial.

Sebagai suatu permukiman yang dikelompokkan berdasarkan etnis tertentu, kultur yang melekat pada komunitas di dalam Kampung Arab Panjunan selalu mendefinisikan kejadian pada suatu ruang, yang kemudian mendefinisikan ruang itu sendiri dan elemen fisik pembentuknya. Oleh karenanya, penelaahan elemen arsitektural yang masih bertahan dan menjadi penciri kawasan dari waktu ke waktu juga perlu dilihat dari segi perspektif warga setempat melalui rekognisi kawasan serta memori warga setempat yang terkait di dalam elemen arsitektural tersebut.

Menurut Kevin Lynch (1960), bentukan fisik merupakan aspek yang paling mudah diamati dalam menganalisis ciri atau kekhasan suatu kawasan karena kesan visual mudah diserap dan dicerna oleh ingatan manusia. Landmark atau tengaran adalah benda atau tempat yang mudah diidentifikasi yang berfungsi sebagai titik referensi eksternal. ${ }^{1}$ Tengaran merupakan titik referensi seperti node, tetapi orang tidak masuk kedalamnya karena bisa dilihat dari luar letaknya. Tengaran adalah elemen eksternal dan memiliki bentuk visual yang menonjol dari Kota, misalnya gunung atau bukit, gedung yang menjulang, menara, tanda tinggi, tempat ibadah, pohon yang tinggi dan lain-lain. Elemen arsitektural ini dapat ditentukan sebagai tengaran atau bukan berdasarkan beberapa kriteria yang dikemukakan oleh Eko Budihardjo, yakni memiliki nilai kesejarahan, nilai arsitektural, nilai keunikan, dan nilai keselarasan.

Setiap upaya untuk menangani interaksi manusia dengan lingkungan harus melibatkan tiga bidang, yaitu mengetahui sesuatu, merasa sesuatu tentang hal itu, dan kemudian melakukan sesuatu tentang hal itu. Ketiga bidang ini dapat dikelompokkan menjadi aspek kognitif, afektif, dan konatif.

Menurut Rapoport, kognitif melibatkan pengamatan dan mengetahui sesuatu serta berpikir, sebagai proses dasar dimana individu mengenali lingkungannya (rekognisi). Rekognisi adalah keadaan yang diakui, pengakuan, pengenalan, penghargaan (KBBI, 2016). Dalam arsitektur, konsep rekognisi berguna untuk mengetahui dimana manusia berada, apa yang tengah terjadi, dan untuk mengenali obyek umum yang ada disekitarnya (Purwanto, 2001). Rekognisi manusia berhubungan erat atau inheren dengan memori karena saat manusia merekognisi sesuatu, secara tidak sadar berlangsung pula tindakan mengingat kembali (recalling) memori atau hal yang menyebabkan seseorang mampu mengenali suatu objek.

Kontinuitas memori dapat didefinisikan sebagai keinginan untuk melestarikan konsep diri dari waktu ke waktu dan situasi di antara masa lalu dan masa kini. Dalam konteks pengenalan lingkungan (rekognisi), kontinuitas memori berpusat pada kisah atau sejarah individu terhadap lingkungannya. Kontinuitas yang berlangsung dari waktu ke waktu ini dibagi ke dalam dua subset yang lebih spesifik; place-referent continuity dan place-congruent continuity. ${ }^{2}$

\footnotetext{
${ }^{1}$ LYNCH, Kevin. 1960. The Image of The City. Cambridge: MIT Press.

${ }^{2}$ BREAKWELL, G. M. 1986. Coping with Threatened Identidentity. London: Methuen
} 


\section{ANALISA}

\subsection{KAMPUNG ARAB PANJUNAN, CIREBON Awal Terbentuknya}

Kawasan Panjunan Cirebon merupakan kawasan permukiman padat dengan karakteristik etnis Arab yang terletak di pusat Kota Cirebon, tepatnya di Kelurahan Panjunan. Permukiman komunitas etnis Arab ini lebih dikenal dengan nama Kampung Arab Panjunan. Penamaan kawasan ini tidak lepas dari profesi yang dilakukan oleh pendatang dari Arab, yakni sebagai pengrajin barang-barang dari gerabah (anjun). Oleh karena itu daerah tersebut kemudian dikenal dengan nama Panjunan yang berasal dari dari kata pa-anjun-an.

Keberadaan Kampung Arab Panjunan tidak lepas dari kedatangan Syarif Abdurrakhman beserta 1200 orang pengikutnya ke pelabuhan Cirebon pada tahun 1464 . Beliau datang bersama tiga orang saudaranya, yakni Syarif Abdulrakhim, Syarif Kapi dan Syarif Baghdad. Keempat orang tersebut adalah putra-putri Sultan Sulaeman dari Baghdad, yang kemudian berguru kepada Syekh Nurjati di Gunung Jati Cirebon. Mereka kemudian memohon ijin kepada Pangeran Cakrabuana dan Syekh Nurjati untuk menetap di Cirebon. Oleh Pangeran Cakrabuana, Syarif Abdurrakhman diijinkan untuk menetap di suatu tempat yang sekarang dikenal dengan nama Panjunan. Syarif Abdurrakhman, sebagai pemimpin pendatang komunitas etnis Arab, diberi gelar kehormatan dengan nama Pangeran Panjunan serta namanya diabadikan sebagai salah satu nama jalan di Kampung Arab Panjunan hingga saat ini.

\section{Karakteristik Elemen Fisik - Jaringan Jalan}

Berdasarkan Perda Kota Cirebon Nomor 8 Tahun 2012 tentang Rencana Tata Ruang Wilayah (RTRW) Kota Cirebon Tahun 2011-2031, jaringan jalan pada Kota Cirebon terbagi atas kelas jalan arteri primer dan sekunder, jalan kolektor primer dan sekunder, serta jalan lingkungan. Jaringan jalan lingkungan sebagaimana dimaksud meliputi semua jalan penghubung antara jalan kolektor sekunder dengan pusat-pusat permukiman.

Berdasarkan Perda di atas, jaringan jalan yang membentuk blok kawasan Panjunan masuk ke dalam kelas jalan lingkungan. Untuk memudahkan pembahasan, penulis membagi hierarki jalan lingkungan yang melintas berdasarkan fungsi jalan terhadap kawasan. Hierarki jalan tersebut meliputi jalan lingkungan primer, sekunder, dan tersier.

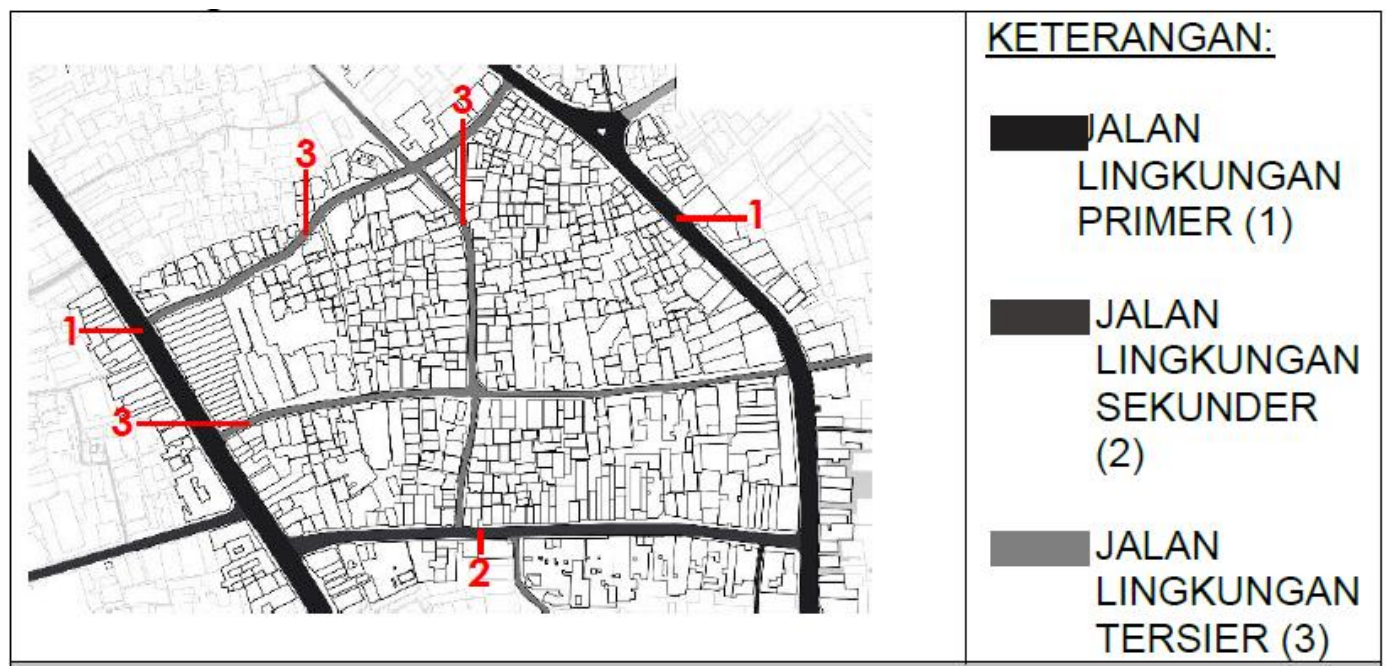

Figur 1. Jaringan Jalan Pembentuk Kawasan Panjunan 


\section{Tata Guna Lahan (Land Use)}

Bangunan pada outer block memiliki kecenderungan tata guna lahan berupa fungsi komersial. Berbeda halnya dengan bangunan dalam inner block yang cenderung berfungsi sebagai hunian. Hal ini tentu dipengaruhi dengan sifat jalan besar yang aktivitasnya lebih ramai dan sering dilalui penduduk, sehingga peluang ekonominya lebih tinggi dan merupakan kesempatan yang baik untuk membuka suatu usaha. Berbeda halnya dengan sifat ruang dalam kantong yang lebih intim, sehingga fungsi di dalamnya cenderung berupa hunian.

Tabel 1. Tata Guna Lahan

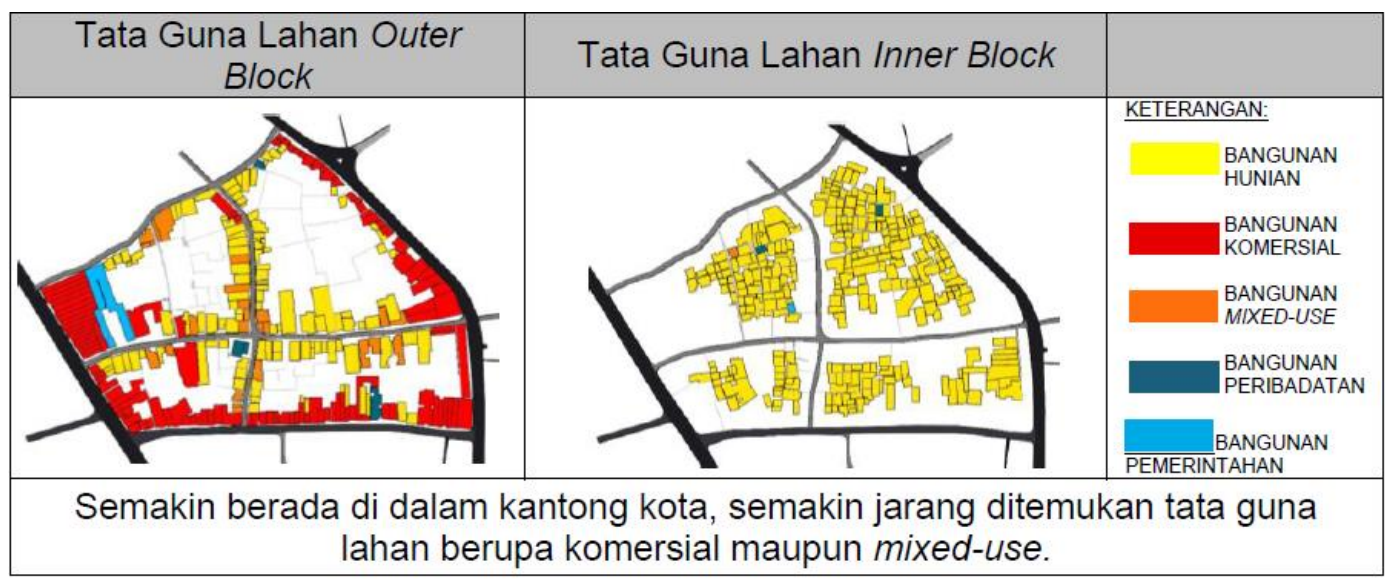

\section{Ketinggian Bangunan}

Bangunan pada outer block memiliki kecenderungan tersusun atas ketinggian 2-3 lantai. Berbeda halnya dengan bangunan dalam inner block yang cenderung memiliki tinggi bangunan satu lantai. Hal ini tentu dipengaruhi juga oleh fungsi bangunan pada masingmasing segmennya (outer atau inner block).

Tabel 2. Ketinggian Bangunan

\begin{tabular}{|l|l|l|}
\hline Ketinggian Bangunan Outer & Ketinggian Bangunan Inner Block & KETERANGAN: \\
\hline Semakin berada di dalam kantong kota, semakin rendah ketinggian bangunan, \\
begitu pula sebaliknya.
\end{tabular}

\section{Area Hijau dan Ruang Jalan sebagai Ruang Terbuka}

Dalam objek studi terdapat beberapa area hijau yang membentuk fisik spasial Kampung Arab. Selain berupa lapangan terbuka, area hijau juga terdapat pada beberapa rumah yang memiliki inner court. Rumah-rumah yang memiliki inner court ini diduga merupakan rumah kaum Arab yang memiliki dimensi kavling cukup besar. Inner court pada rumah tinggal islami merupakan salah satu wujud keseimbangan manusia dengan lingkungan 
ciptaan Tuhan. Selain itu, massa bangunan yang berada di sepanjang deret jalan membingkai sebuah ruang jalan menjadi sebuah ruang terbuka.
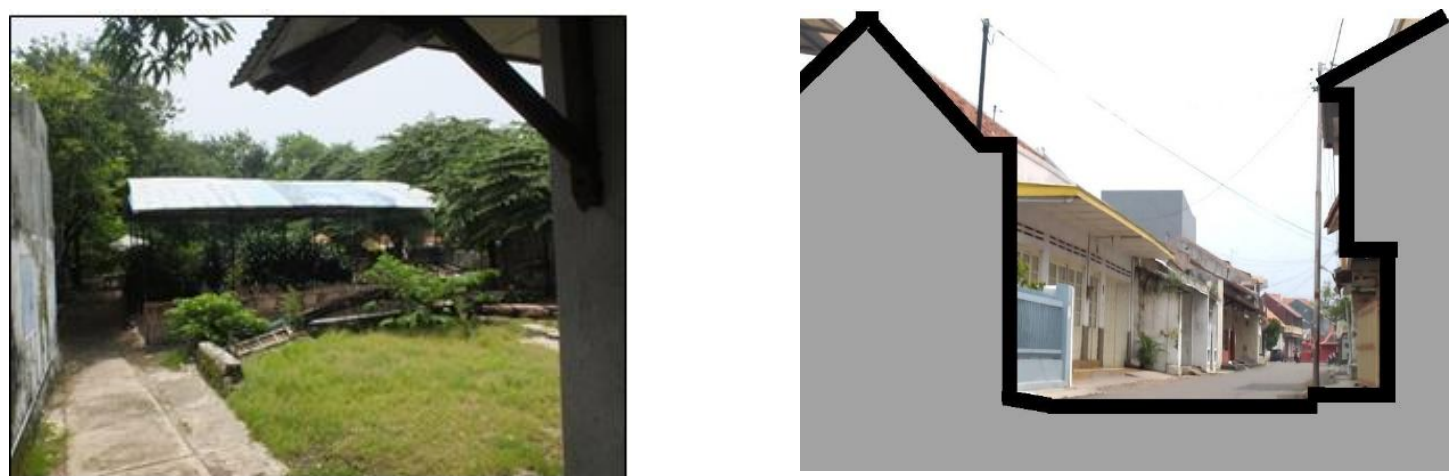

Figur 2. Ruang Terbuka

\section{Karakteristik Sosial}

Keturunan etnis Arab yang mayoritas beragama Islam memberikan karakter sosial yang khas pada Kampung Arab Panjunan. Permukiman etnis Arab cenderung memiliki masjid yang terkait dengan mereka, sebagaimana yang terdapat pada permukiman di tanah Arab. Masjid merupakan elemen intrinsik dari masyarakat Islam dan perlu dilihat bukan hanya sebagai tempat ibadah tetapi sebagai bagian penting dari setiap daerah perumahan, dalam arti yang menjadi perpanjangan dari rumah. Masjid disediakan dalam jarak berjalan kaki dari semua perumahan biasanya atas dasar sekitar satu masjid ke enam puluh atau tujuh puluh rumah (1 masjid melayani 60-70 rumah).



Figur 3. Persebaran Masjid dan Mushola di Kampung Arab Panjunan

Agama Islam yang dianut oleh warga Kampung Arab Panjunan terbagi ke dalam dua golongan, yaitu golongan Habib dan Ghabili. Kedua golongan ini memiliki ajaran agama yang sedikit berbeda satu sama lain sehingga menyebabkan terciptanya dua masjid utama 
yang berbeda peruntukannya, yaitu Masjid Merah Panjunan untuk golongan Habib dan Masjid Asy Syafi'i (Bayasut) untuk golongan Ghabili.
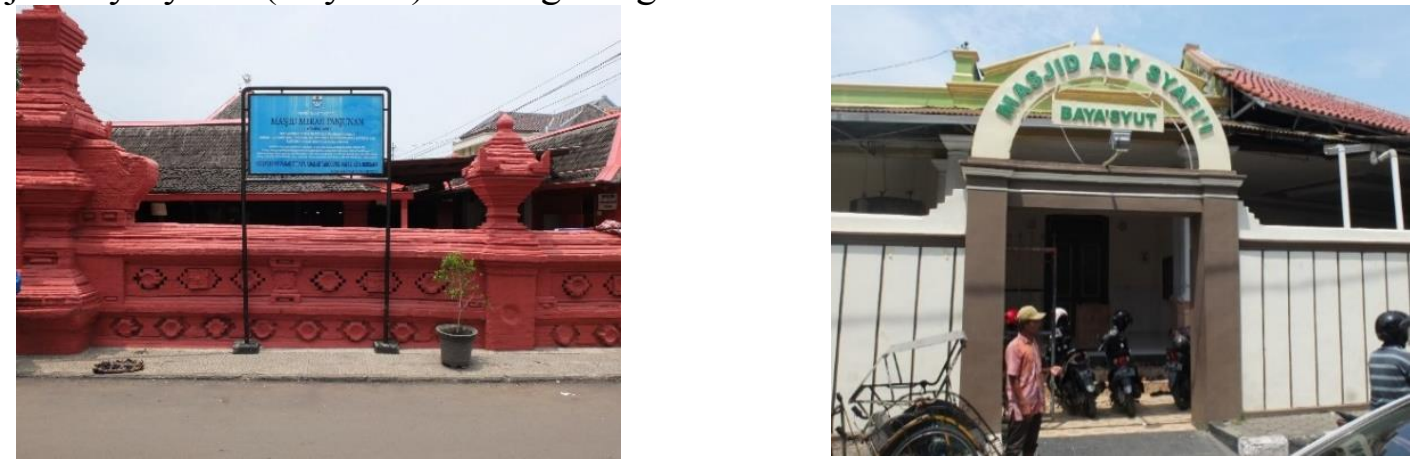

Figur 4. Masjid Merah Panjunan (Kiri) dan Masjid Asy Syafi'i (Kanan)

\section{Karakteristik Budaya}

Budaya bermukim komunitas etnis Arab menyebabkan persebaran pemukiman sering kali dipengaruhi oleh adanya hubungan pertalian keluarga di dalam komunitas tersebut. Rumah-rumah yang dihuni oleh beberapa keluarga bermarga sama akan saling berdekatan. ${ }^{3}$ Penempatannya dapat berbentuk dalam suatu deret terhadap jalan (linier) atau mengelompok (cluster) dalam satu petak kaveling.
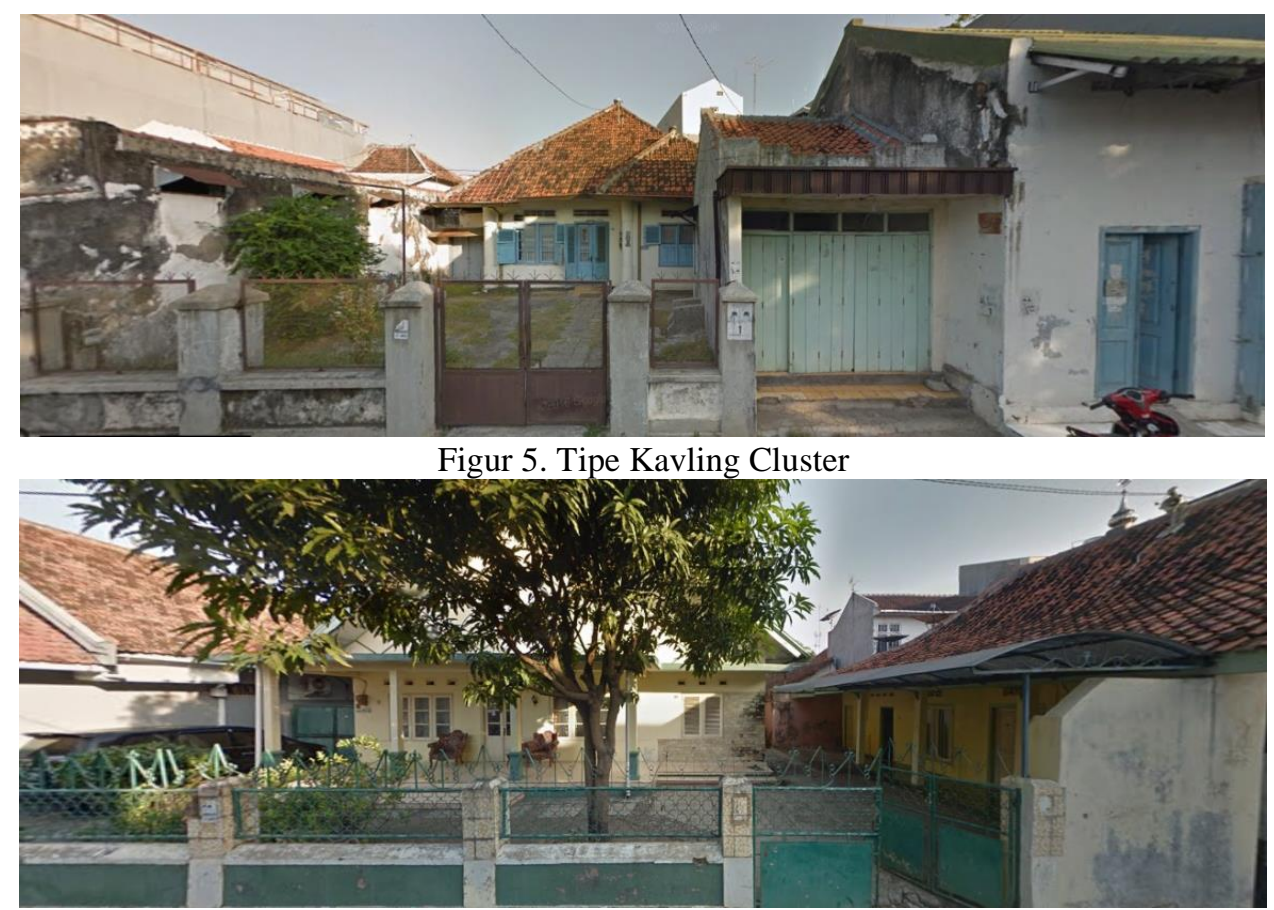

Figur 6. Tipe Kavling Cluster
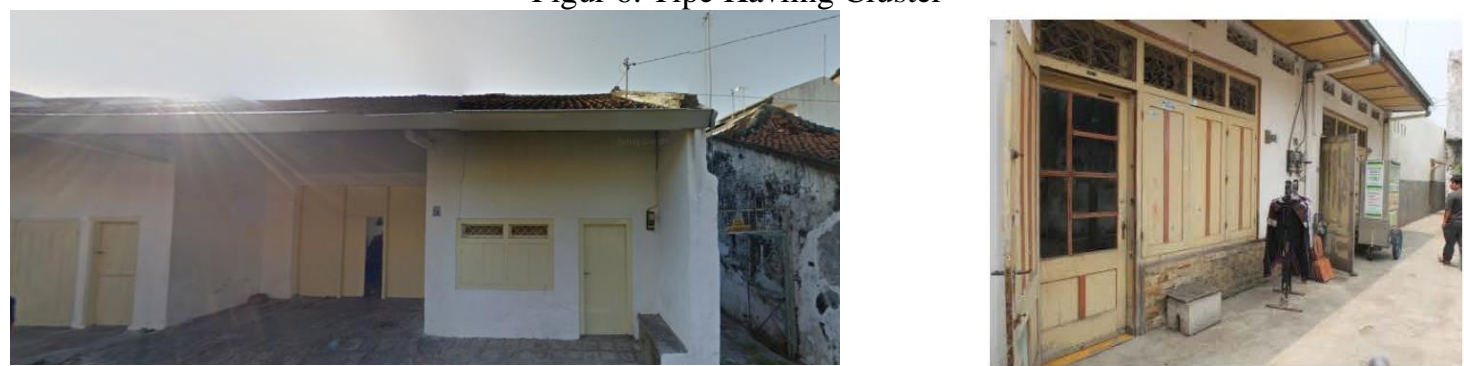

Figur 7. Tipe Kavling Deret

\footnotetext{
${ }^{3}$ WIDODO, Johannes. 1996. The Urban History of Southeast Asian Coastal Cities.
} 


\section{Aplikasi Budaya Bermukim Komunitas Etnis Arab pada Rumah Tinggal}

Budaya bermukim khas komunitas etnis Arab tak hanya berhenti pada tatanan massa saja, melainkan juga hingga organisasi ruang dalam huniannya. Dalam arsitektur, budaya masyarakat Arab yang membatasi interaksi pria dan wanita (yang bukan keluarga muhrim) terwujud dalam penggunaan hijab. Hijab dalam aplikasi arsitektural pada prinsipnya adalah pemisahan yang tegas antara zona publik yang identik dengan zona pria (birun) dan zona privat untuk wanita (anderun). ${ }^{4}$

Tabel 3. Ruang Dalam Rumah Tinggal Komunitas Etnis Arab

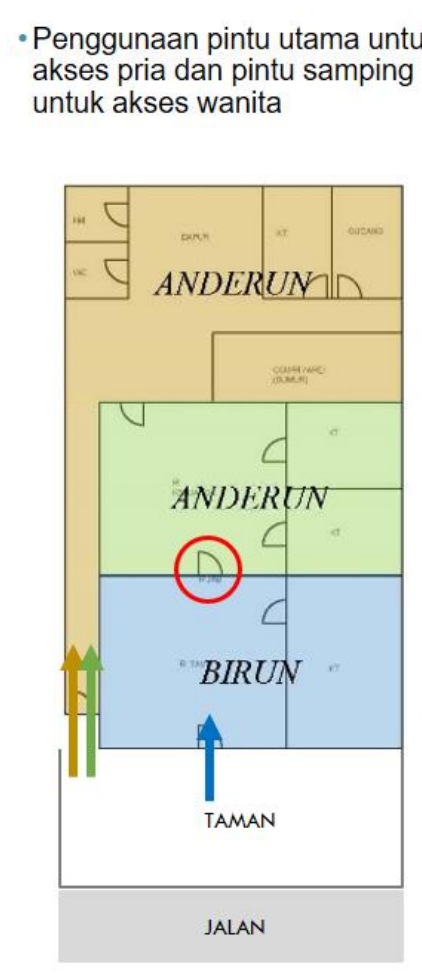

\section{- Pintu/tirai/lorong panjang pembatas ruang tamu dan ruang keluarga (hijab).}

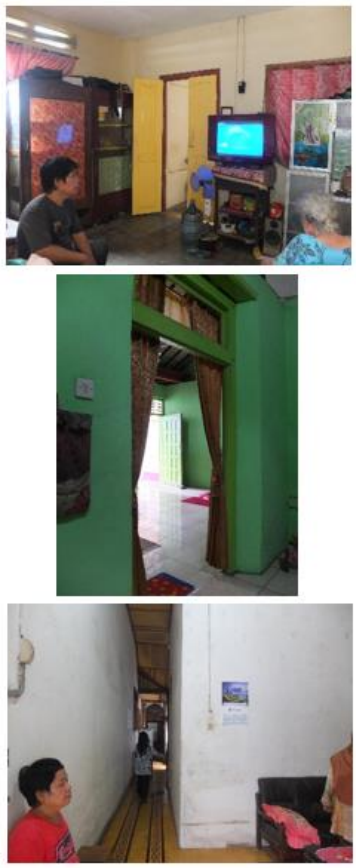

- Amben dengan permadani (karpet) di ruang tamu untuk area istirahat \& sholat tamu
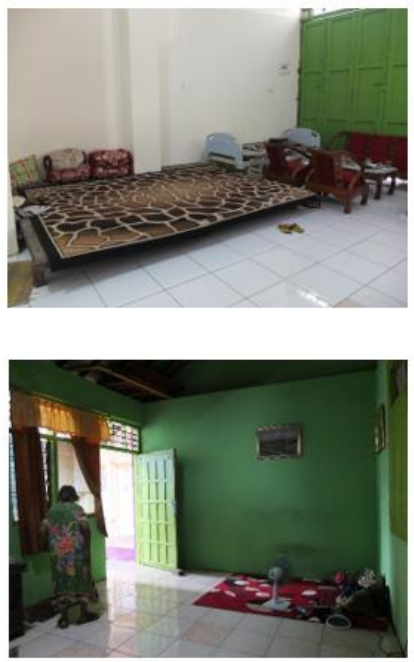

\section{Toponimi pada Kampung Arab Panjunan}

Beberapa penamaan tempat pada Kampung Arab Panjunan menggunakan nama-nama yang berhubungan dengan keprofesian dan tokoh masyarakat yang dikenal dari tahun ke tahun selama masa perkembangan Kampung Arab itu sendiri.

\footnotetext{
${ }^{4}$ ASTUTI, Sri Puji. 1986. Konsepsi Perencanaan Organisasi Ruang Islami. Pena Jurnal Ilmu Pengetahuan dan Teknologi, 26 (2).
} 


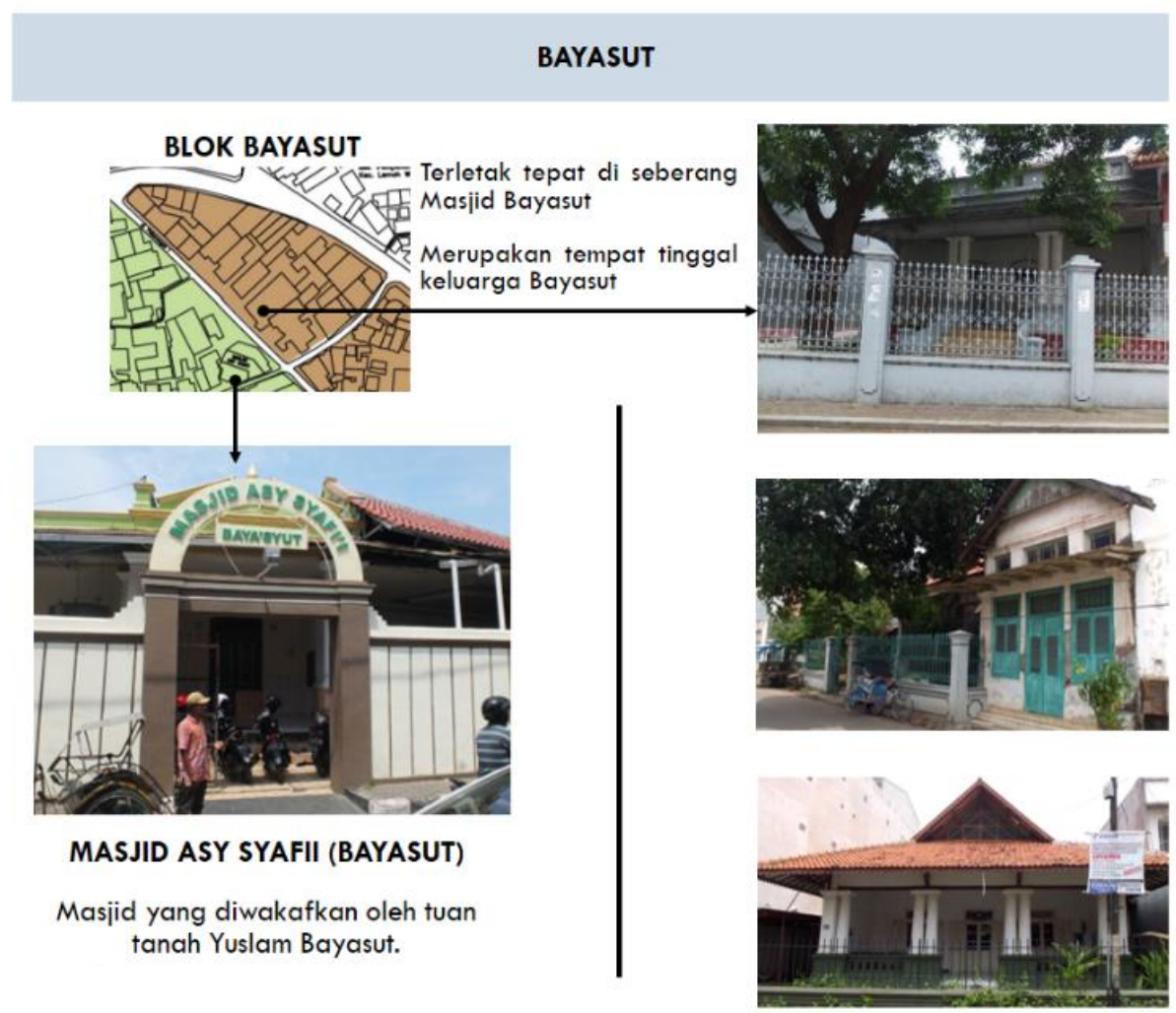

Figur 8. Toponimi Sesuai Nama Tokoh Masyarakat



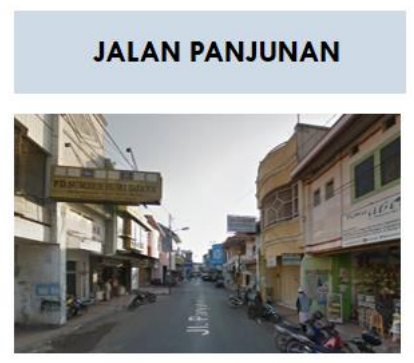

Pa-anjun-an

Dinamakan berdasarkan profesi warga di dalamnya yang mayoritas merupakan pengrajin gerabah (anjun).

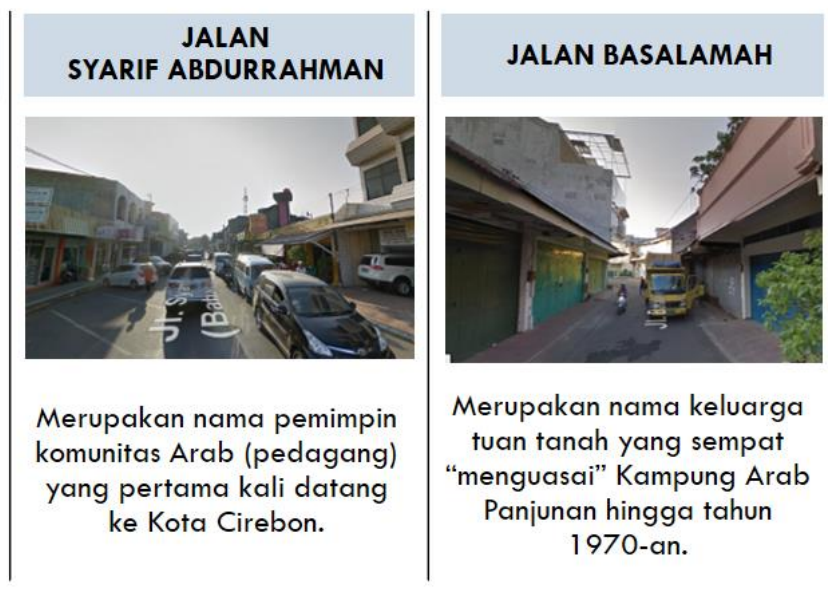

Figur 9. Toponimi Sesuai Profesi 


\subsection{REKOGNISI DAN MEMORI KOMUNITAS LOKAL PADA ELEMEN ARSITEKTURAL DI KAMPUNG ARAB PANJUNAN CIREBON}

Rekognisi manusia terhadap suatu elemen arsitektur akan menunjukkan adanya kemungkinan bahwa elemen tersebut berlaku sebagai tengaran. Sedangkan Memori pada elemen yang direkognisi akan berpengaruh pada pemaknaan elemen tengaran tersebut.

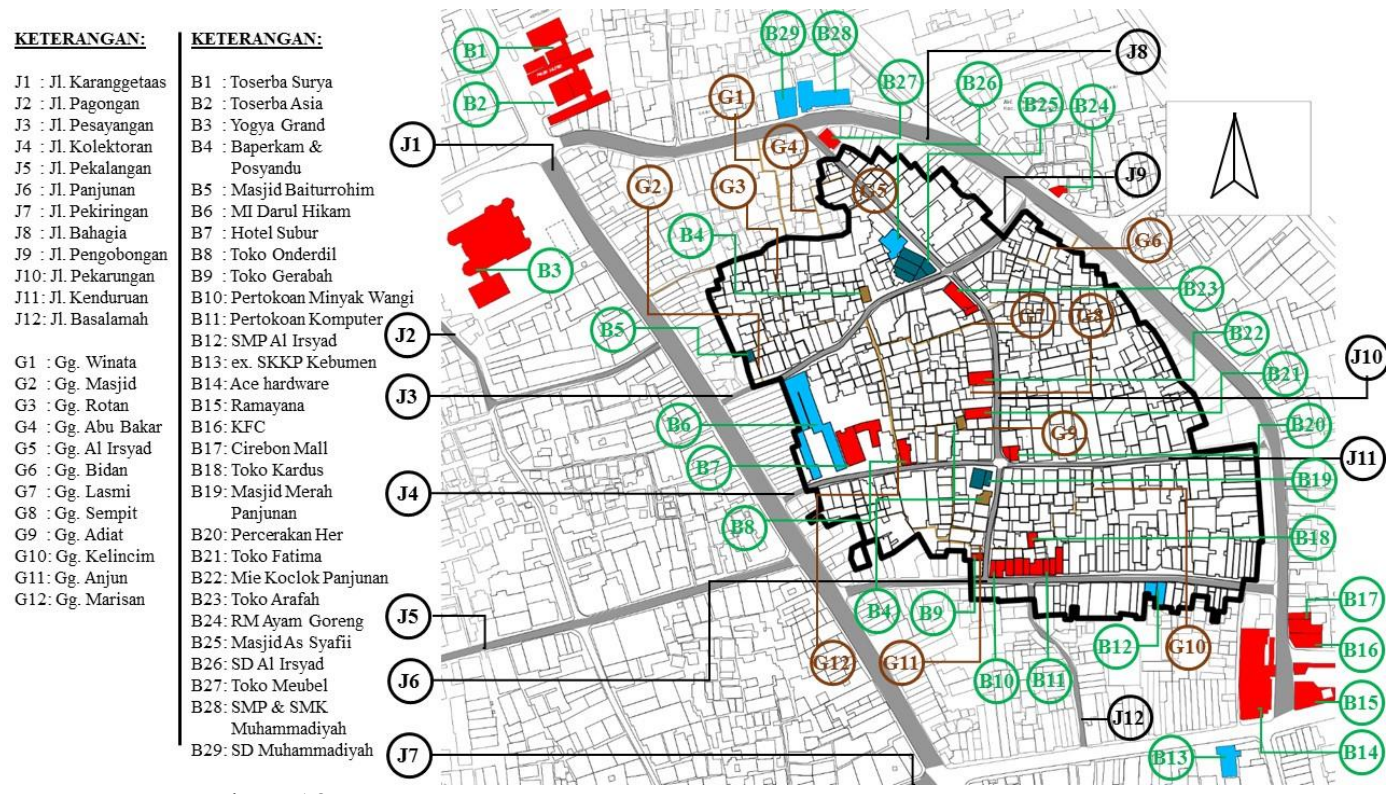

Figur 10. Elemen Arsitektural di Kampung Arab Panjunan yang Direkognisi

\section{Berdasarkan Keturunan}

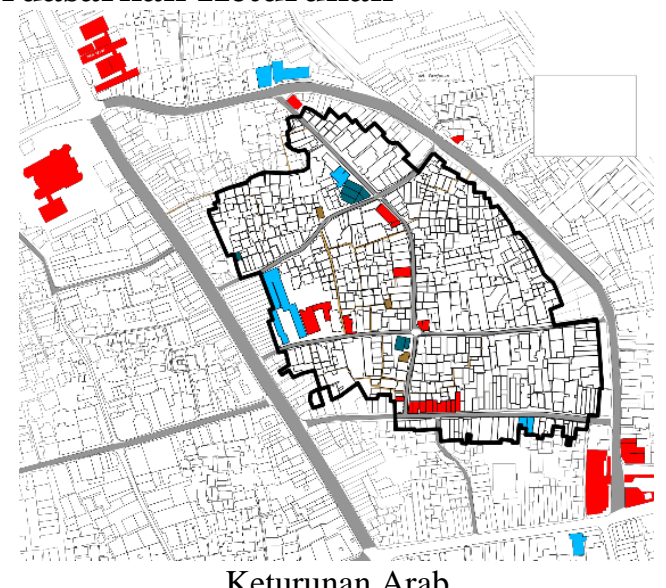

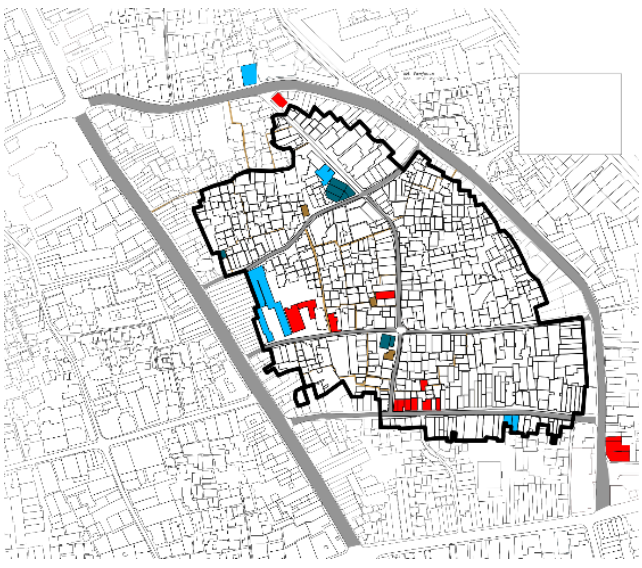

Keturunan Non-Arab

Berdasarkan pemetaan identifikasi elemen lingkungan di samping ditemukan bahwa warga keturunan etnis Arab cenderung mampu mengidentifikasi elemen lingkungan yang berada di dalam Kampung Arab Panjunan maupun yang berada di luar atau sekitarnya, sehingga dapat dikatakan bahwa warga keturunan etnis Arab memiliki daya rekognisi terhadap Kampung Arab Panjunan yang cukup luas. Sedangkan warga keturunan etnis nonArab cenderung hanya mengidentifikasi elemen lingkungan yang berada di dalam wilayah Kampung Arab Panjunan sehingga dapat dikatakan bahwa warga keturunan etnis non-Arab memiliki daya rekognisi terhadap Kampung Arab Panjunan yang cenderung mengarah ke dalam. 

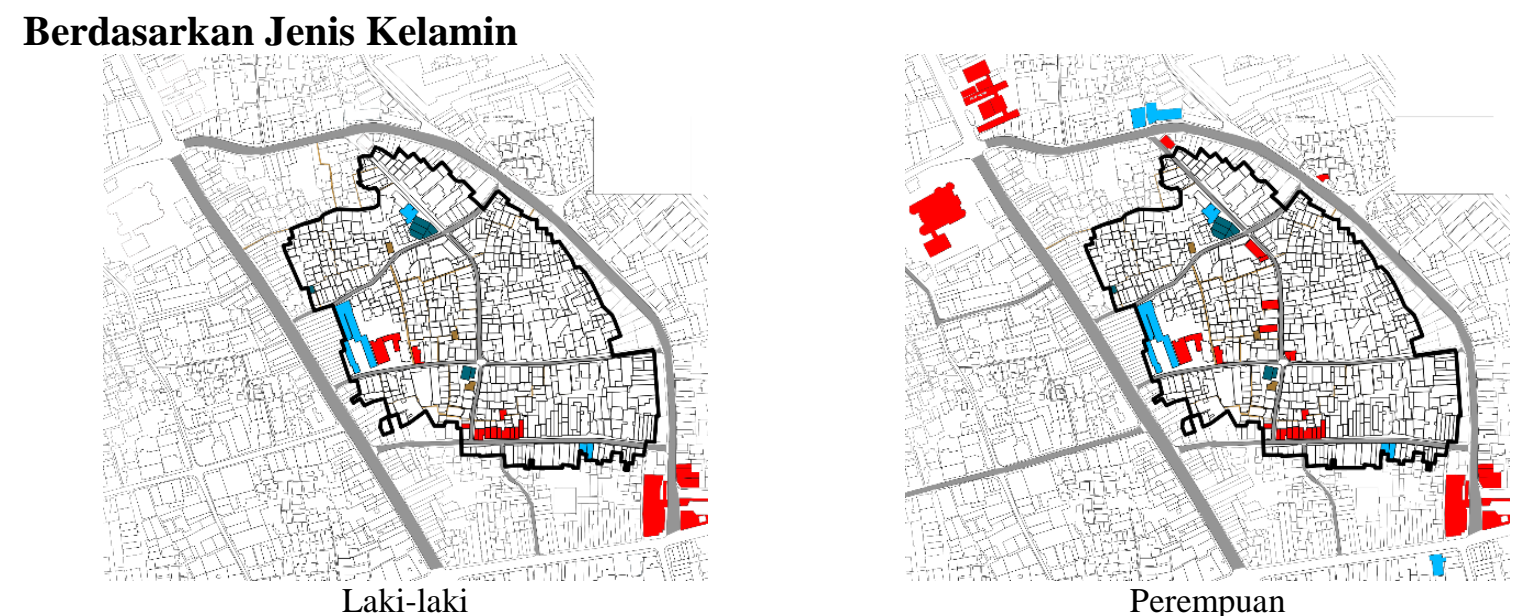

Figur 12. Perbandingan Elemen Arsitektural di Kampung Arab Panjunan yang Direkognisi Warga Laki-Laki dan Perempuna

Berdasarkan pemetaan identifikasi elemen lingkungan di atas ditemukan bahwa daya rekognisi perempuan justru cenderung lebih mampu mengidentifikasi elemen lingkungan yang berada di dalam Kampung Arab Panjunan maupun yang berada di laki-laki. Perempuan merekognisi elemen arsitektural yang berada di dalam Kampung Arab Panjunan maupun yang berada di luar (keterkaitannya aktivitas tempat belanja). Responden laki-laki cenderung hanya merekognisi elemen arsitektural yang berada di dalam wilayah Kampung Arab Panjunan (kaitannya dengan tempat bekerja).

\section{Rekognisi Elemen Arsitektural Berupa Jalan}

Jalan Kolektoran memiliki frekuensi rekognisi yang tinggi dan merata pada persepsi responden terhadapnya. Selain itu, Jalan Kenduruan, Jalan Pekarungan, dan Jalan Panjunan memiliki frekuensi yang tinggi, walau pada salah kelompok tidak terlalu merata distribusi rekognisinya.
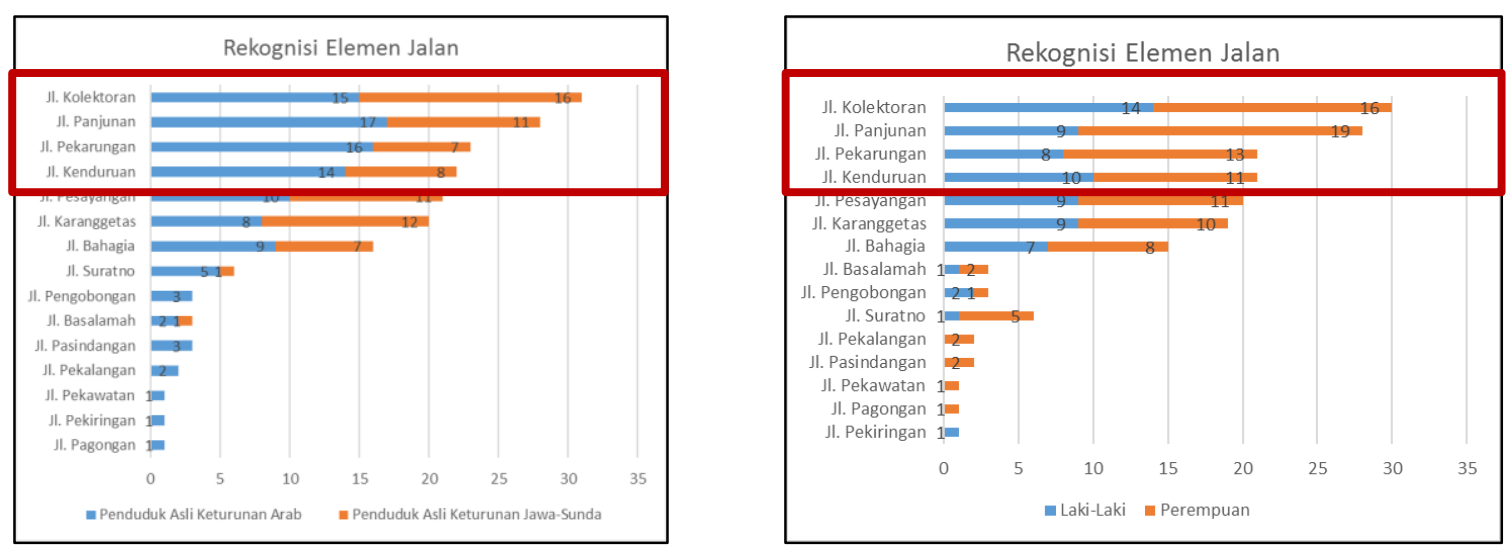

Figur 13. Dominasi Rekognisi Elemen Arsitektural Berupa Jalan

Elemen arsitektural jalan memiliki kecenderungan menjadi elemen yang kaya akan place-referent continuity yakni konsentrasi memori terkait tindakan dan kejadian yang lalu, tempat-tempat bersejarah, dan kaitan peristiwa lalu dengan masa kini pada individu responden. Elemen arsitektural yang bekerja sebagai place-referent recall memori akan suatu tempat yang memiliki keterkaitan dengan pribadi setiap individu. Dengan demikian, placereferent dapat juga dikonsepkan sebagai identitas diri. 
Tabel 4. Perbandingan Place-Referent dan Place-Congruent Continuity



Berdasarkan tabel di atas, diketahui bahwa aspek place-referent continuity pada Jalan Kolektoran dan Jalan Panjuan lebih dominan dibanding dengan aspek place-congruent continuity yang dimilikinya. Jalan Kolektoran dan Jalan Panjunan memiliki kecenderungan dikenali sebagai elemen arsitektural yang mengandung memori yang berhubungan dengan individu dibanding dengan memori yang berhubungan dengan komunitas. Artinya, elemen arsitektural ini memiliki keterikatan dengan responden atau bisa jadi dengan warga Kampung Arab Panjunan secara umum pada segi emosional tingkat pribadi, khususnya yang terkait dengan kejadian masa lampau dan masa kini responden.

Aspek place-referent continuity dan aspek place-congruent continuity pada Jalan Panjunan dan Jalan Pekarungan cenderung mendekati seimbang. Jalan Panjunan dan Jalan Pekarungan tak hanya memiliki kecenderungan dikenali sebagai elemen arsitektural yang mengandung memori yang berhubungan dengan individu, tetapi juga dikenali sebagai elemen arsitektural yang di dalamnya memori terkait komunitas. Artinya, elemen arsitektural ini memiliki keterikatan dengan responden atau bisa jadi dengan warga Kampung Arab Panjunan secara umum pada segi emosional tingkat pribadi dan komunitas. Sehingga dapat disimpulkan bahwa Jalan Panjunan dan Jalan Pekarungan memiliki kontinuitas memori pada skala komunitas atau kolektif. 


\section{Rekognisi Elemen Arsitektural Berupa Bangunan.}

Masjid Merah Panjunan memiliki frekuensi yang merata pada rekognisi responden terhadapnya. Selain itu, Masjid Asy Syafi'i dan MI Darul Hikam juga memiliki frekuensi rekognisi yang tinggi, walau pada salah satu kelompok tidak terlalu merata.
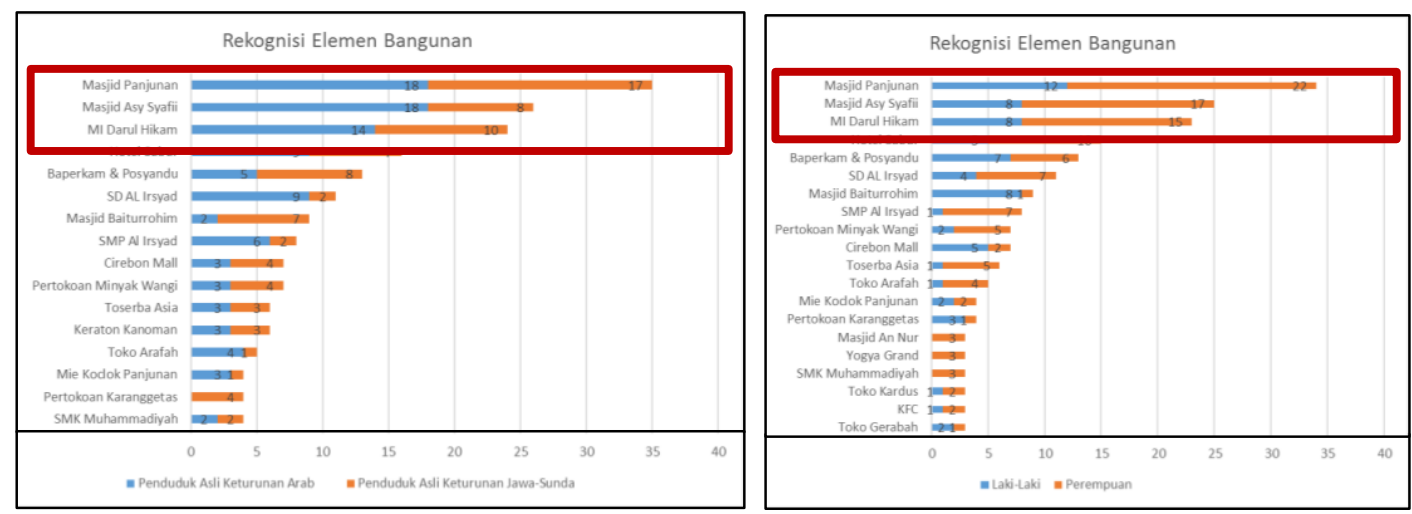

Figur 14. Dominasi Rekognisi Elemen Arsitektural Berupa Bangunan

Elemen arsitektural bangunan memiliki kecenderungan menjadi elemen yang kaya akan place-congruent continuity karena konsentrasi memori terkait tradisi, keinginan, dan sosial. Ketiga aspek ini lebih terwadahi pada elemen fisik bangunan dibanding jalan. Aspekaspek seperti tradisi, keinginan, dan sosial, dapat dirumuskan sebagai memori yang terkait dengan suatu komunitas. Dengan demikian, place-congruent dapat juga dikonsepkan sebagai identitas komunitas.

Aspek place-congruent continuity pada Masjid Merah Panjunan dan Masjid Asy Syafi'i lebih dominan dibanding dengan aspek place-referent continuity yang dimilikinya. Masjid Merah Panjunan memiliki kecenderungan dikenali sebagai elemen arsitektural yang mengandung memori yang berhubungan dengan komunitas dibanding dengan memori yang berhubungan dengan individu. Artinya, elemen arsitektural ini memiliki keterikatan dengan responden atau bisa jadi dengan warga Kampung Arab Panjunan secara umum pada segi emosional tingkat komunitas yang menggunakan masjid ini sebagai tempat ibadah, khususnya yang terkait dengan tradisi.

Namun aspek place-referent continuity pada MI Darul Hikam lebih dominan dibanding dengan aspek place-congruent continuity yang dimilikinya. MI Darul Hikam memiliki kecenderungan dikenali sebagai elemen arsitektural yang mengandung memori yang berhubungan dengan individu dibanding dengan memori yang berhubungan dengan komunitas. Hal ini diduga disebabkan karena fungsi bangunannya sebagai sekolah yang sebagian besar hanya diingat sebagai tempat belajar sewaktu kecil. Sehingga dapat disimpulkan bahwa Masjid Merah Panjunan dan Masjid Asy Syafi'i memiliki kontinuitas memori pada skala komunitas atau kolektif. 
Tabel 5. Perbandingan Place-Referent dan Place-Congruent Continuity

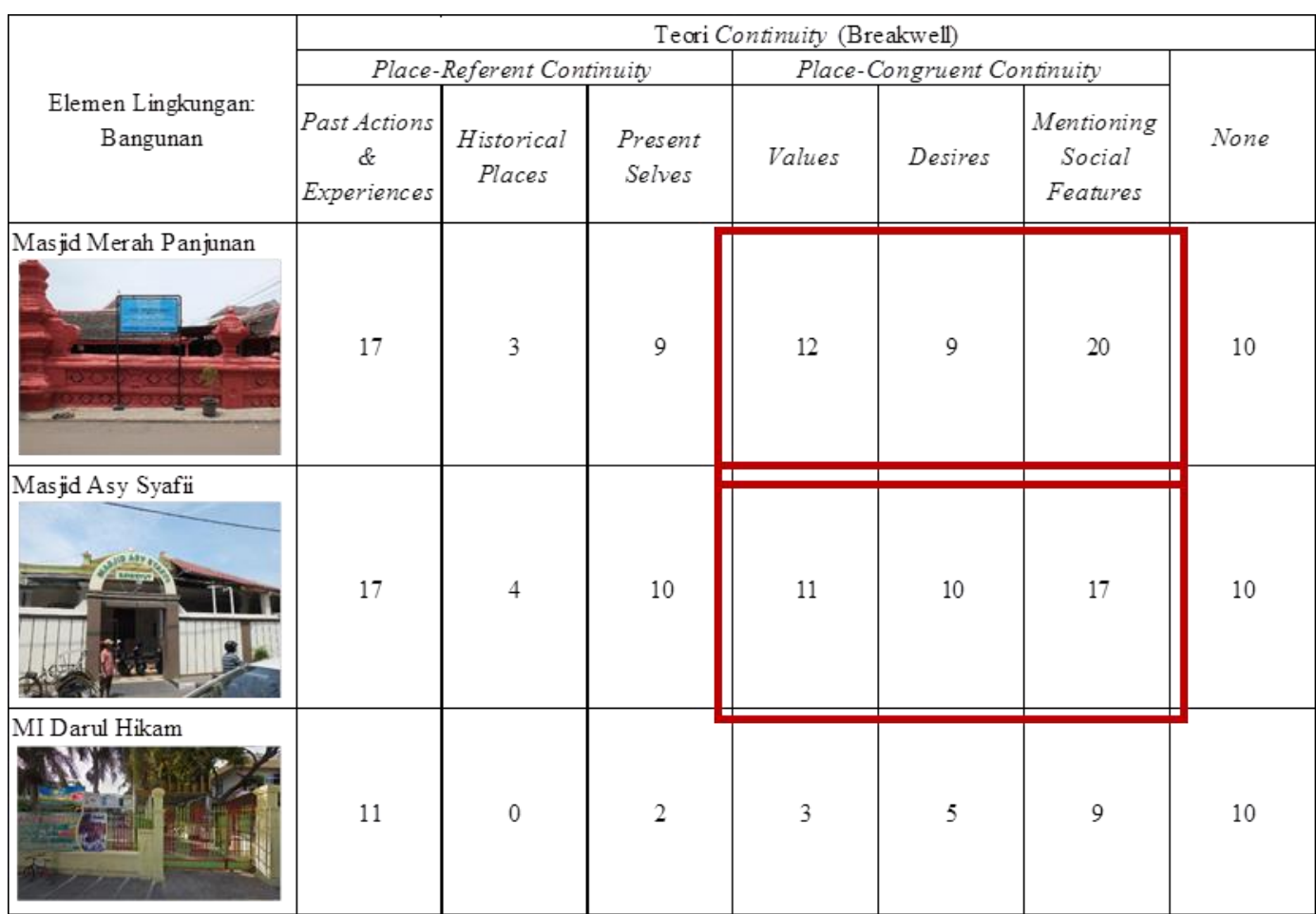

\subsection{MASJID MERAH PANJUNAN DAN MASJID ASY SYAFI'I SEBAGAI TENGARAN BERDASARKAN REKOGNISI KOMUNITAS LOKAL}

Unsur penting yang mendasari elemen tengaran adalah apabila ia memiliki bentuk yang jelas, kontras dengan latarnya, dan apabila lokasi di mana ia berdiri merupakan sebuah tempat yang penting. Tengaran juga dapat menjadi kuat apabila ia memiliki sejarah, tanda, atau makna. Jarak penglihatan sebuah tengaran dari berbagai titik pada suatu wilayah dapat membuatnya menjadi penanda yang kuat. Adapun kriteria yang menjadikan suatu elemen arsitektur menjadi tengaran adalah memiliki kesejarahan, memiliki nilai arsitektural, memiliki nilai kekhasan atau keunikan, dan memiliki nilai keselarasan. Elemen arsitektural yang akan dianalisa pada bab ini adalah elemen arsitektural yang memiliki kontinuitas memori pada skala komunitas atau kolektif (place-congruent) yang telah ditemukan pada bab sebelumnya, yakni Jalan Panjunan, Jalan Pekarungan, Masjid Merah Panjunan, dan Masjid Asy Syafi'i.

Sebuah elemen arsitektural dapat menjadi elemen tengaran yang kuat apabila ia memiliki bentuk yang jelas, kontras dengan latarnya, dan apabila lokasi di mana ia berdiri merupakan sebuah tempat yang penting. Tengaran juga dapat menjadi kuat apabila ia memiliki sejarah, tanda, atau makna. Jarak penglihatan sebuah tengaran dari berbagai titik pada suatu wilayah dapat membuatnya menjadi penanda yang kuat. Setelah tiap elemen dianalisa berdasarkan unsur penting suatu tengaran tersebut, dilakukan pengecekan apakah elemen tersebut memenuhi sebagai suatu tengaran berdasarkan kriteria sebagai berikut. 
Tabel 6. Kriteria Elemen Tengaran

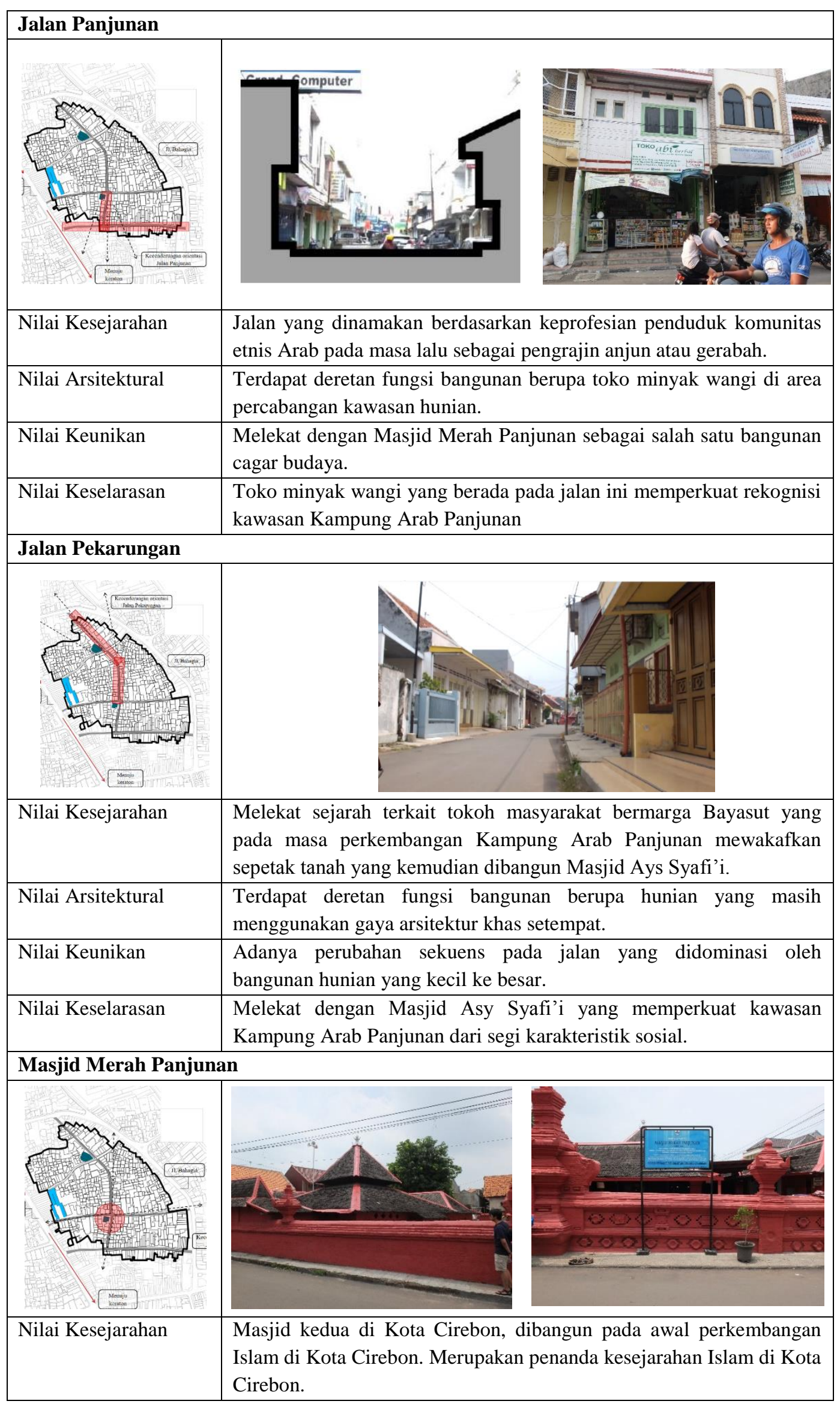




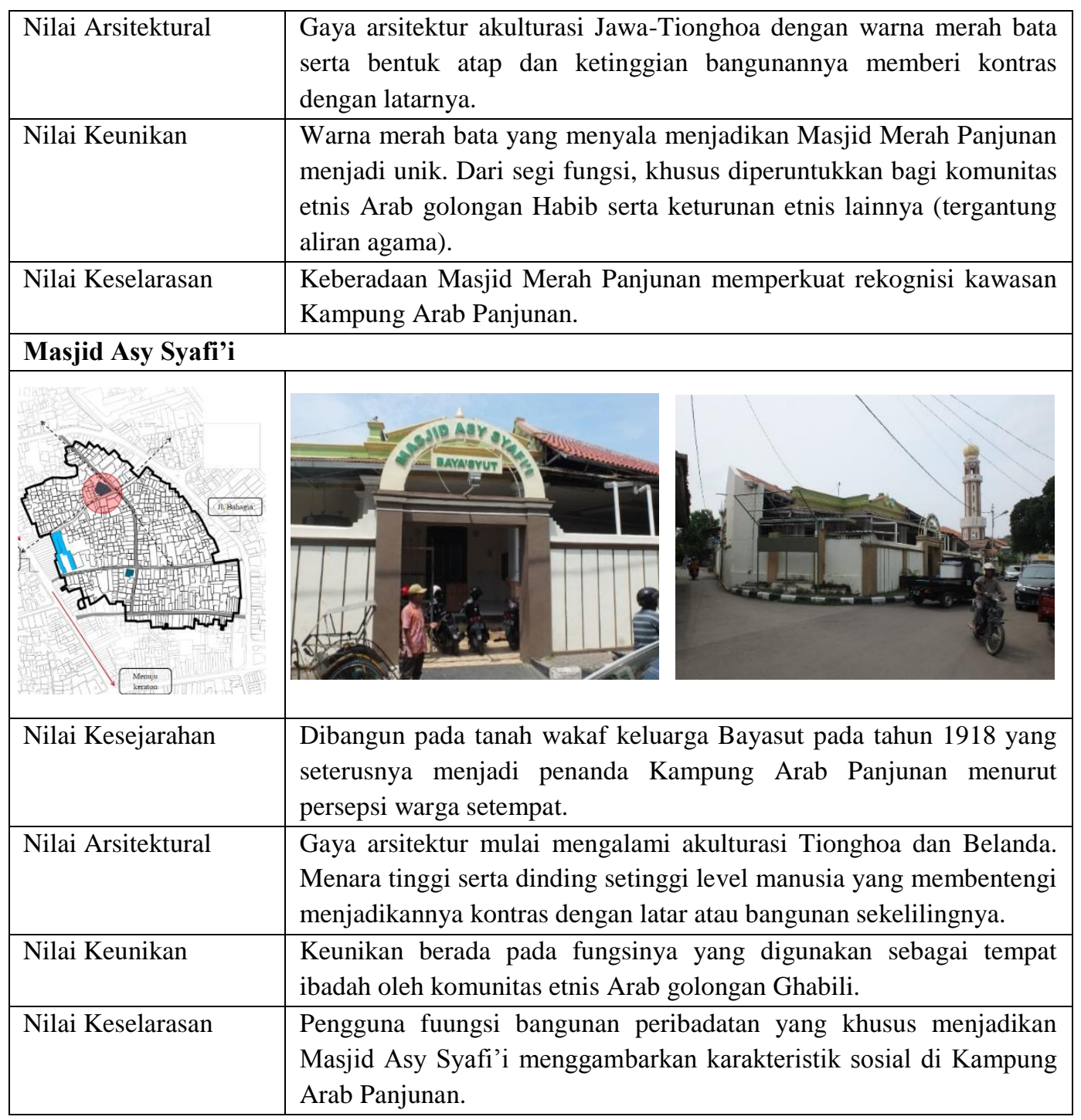

Berdasarkan tabel di atas, Jalan Panjunan berperan menjadi pembentuk tengaran Masjid Merah Panjunan, sedangkan Jalan Pekarungan berperan menjadi pembentuk tengaran Masjid Asy Syafi'i. Kedua jalan ini tidak dilihat sebagai suatu elemen yang berdiri sendiri, melainkan satu kesatuan dengan bangunan yang menjadi tengaran di dalamnya. Konteks kawasan yang merupakan kampung kota menjadikan jalan memiliki peran yang tinggi dalam mengarahkan dan membentuk suatu tengaran. Hal ini disebabkan minimnya ruang (terbuka) yang dapat menjadi area untuk melihat tengaran dengan jelas.

Baik Masjid Merah Panjunan maupun Masjid Asy Syafi'i merupakan elemen tengaran pada Kampung Arab Panjunan, menurut persepsi warga setempat. Masjid Merah Panjunan diinterpretasikan sebagai elemen tengaran yang memiliki lingkup hingga skala kota, artinya bangunan ini dikenal sebagai penciri kawasan Kampung Arab Panjunan maupun Kota Cirebon itu sendiri. Sedangkan Masjid Asy Syafi'i diinterpretasikan sebagai elemen tengaran yang memiliki lingkup hingga skala kawasan. Artinya, masjid ini hanya melekat dan dikenali sebagai penciri oleh warga setempat dan sekitarnya saja, namun tidak sebagai penciri Kota Cirebon. 


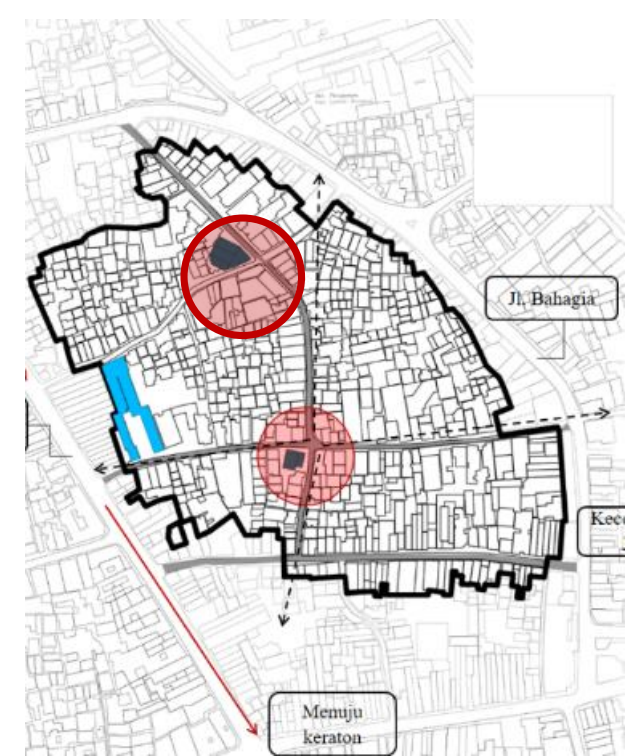

Figur 15. Temuan Elemen Tengaran

\section{PENUTUP}

Elemen arsitektur berupa jalan memiliki kecenderungan menjadi elemen yang kaya akan place-referent continuity. Konsentrasi memori terkait tindakan dan kejadian yang lalu, tempat-tempat bersejarah, dan kaitan peristiwa lalu dengan masa kini pada individu responden. elemen arsitektural yang bekerja sebagai place-referent recall memori akan suatu tempat yang memiliki keterkaitan dengan pribadi setiap individu. Dengan demikian, placereferent dapat juga dikonsepkan sebagai identitas diri.

Elemen arsitektur berupa bangunan memiliki kecenderungan menjadi elemen yang kaya akan place-congruent continuity. Konsentrasi memori terkait tradisi, keinginan, dan sosial. Ketiga aspek ini lebih terwadahi pada elemen fisik bangunan dibanding jalan. Aspekaspek seperti tradisi, keinginan, dan sosial, dapat dirumuskan sebagai memori yang terkait dengan suatu komunitas. Dengan demikian, place-congruent dapat juga dikonsepkan sebagai identitas komunitas (kolektif).

Aspek place-referent continuity dan aspek place-congruent continuity pada Jalan Panjunan dan Jalan Pekarungan cenderung mendekati seimbang. Jalan Panjunan dan Jalan Pekarungan tak hanya memiliki kecenderungan dikenali sebagai elemen arsitektural yang mengandung memori yang berhubungan dengan individu, tetapi juga dikenali sebagai elemen arsitektural yang di dalamnya memori terkait komunitas. Artinya, elemen arsitektural ini memiliki keterikatan dengan responden atau bisa jadi dengan warga Kampung Arab Panjunan secara umum pada segi emosional tingkat pribadi dan komunitas. Sehingga dapat disimpulkan bahwa Jalan Panjunan dan Jalan Pekarungan memiliki kontinuitas memori pada skala komunitas atau kolektif.

Masjid Merah Panjunan dan Masjid Asy Syafi'i memiliki keterikatan dengan responden atau bisa jadi dengan warga Kampung Arab Panjunan secara umum pada segi tingkat komunitas yang menggunakan masjid ini sebagai tempat ibadah, khususnya yang terkait dengan tradisi. MI Darul Hikam memiliki kecenderungan dikenali sebagai elemen arsitektural yang mengandung memori yang berhubungan dengan individu (tempat sekolahnya pada masa lalu). Dengan demikian, dapat disimpulkan bahwa elemen fisik lingkungan yang memiliki kontinuitas memori adalah Masjid Merah Panjunan dan Masjid Asy Syafi'i.

Baik Masjid Merah Panjunan maupun Masjid Asy Syafi'i merupakan elemen tengaran pada Kampung Arab Panjunan, menurut persepsi warga setempat. Masjid Merah Panjunan diinterpretasikan sebagai elemen tengaran yang memiliki lingkup hingga skala 
kota, artinya bangunan ini dikenal sebagai penciri kawasan Kampung Arab Panjunan maupun Kota Cirebon itu sendiri. Sedangkan Masjid Asy Syafi'i diinterpretasikan sebagai elemen tengaran yang memiliki lingkup hingga skala kawasan. Artinya, masjid ini hanya melekat dan dikenali sebagai penciri oleh warga setempat dan sekitarnya saja, namun tidak sebagai penciri Kota Cirebon.

Jalan Panjunan dan Jalan Pekarungan berperan menjadi pembentuk tengaran Masjid Merah Panjunan dan Masjid Asy Syafi'i. Kedua jalan ini tidak dilihat sebagai suatu elemen yang berdiri sendiri, melainkan satu kesatuan dengan bangunan yang menjadi tengaran di dalamnya. Konteks kawasan yang merupakan kampung kota menjadikan jalan memiliki peran yang tinggi dalam mengarahkan dan membentuk suatu tengaran. Hal ini disebabkan minimnya ruang (terbuka) yang dapat menjadi area untuk melihat tengaran dengan jelas..

\section{DAFTAR PUSTAKA}

Abel, Chris. (1997). Architecture \& Identity. London: The Architectural Press.

Aryati, Allafa, dkk. (2012). Perubahan Morfologi Rumah Tinggal di Kampung Arab Kota Malang. Tesa Arsitektur Journal of Architectural Discourse. Semarang: Universitas Katolik Soegijaprana.

Astuti, Sri Puji. (2002). Rumah Tinggal Etnis Keturunan Arab di Pekalongan. Tesis tidak diterbitkan. Semarang: Universitas Diponegoro.

BAPPEDA. (2014). Rencana Aksi Kota Pusaka Cirebon. Cirebon.

Breakwell, G. M. (1986). Coping with Threatened Identity. London: Methuen.

Heidari, Ali Akbar. (2013). Place Identity and Its Informant Parameters in Architectural Studies. Disertasi pada Iran University of Science and Technology.

Listianti, Mirna. (2002). Pembagian Ruang Publik dan Privat Pada Kampung Arab di Pekalongan. Skripsi tidak diterbitkan. Bandung: Universitas Katolik Parahyangan

Lynch, Kevin. (1960). The Image of The City. Cambridge: MIT Press.

Moneo, Rafael. (1978). On Typology: Oppositions 13. Cambridge: MIT Press.

Perwira, I Made. (2013). VARIASI POLA TATA RUANG RUMAH TINGGAL KOMUNITAS ETNIS ARAB DI EMPANG BOGOR. Skripsi tidak diterbitkan. Bandung: Universitas Katolik Parahyangan

Petherbridge, Guy T. (1978). Vernacular Architecture : The House and Society. London : Thames and Hudson

Shirvani, Hamid. (1985). The Urban Design Process. New York: Van Nostrand Reinhold Company.

Twigger-Ross, Clare L. dan David L. Uzzel. (1996). Place and Identity Processes. Journal of Environmental Psychology. Academic Press Ltd 